\title{
Chapter 10 \\ Temporally and Spatially Dependent Nitrogen Management for Diverse Environments
}

\author{
William R. Raun, Ivan Ortiz-Monasterio, and John B. Solie
}

\section{SUMMARY}

(1) As annual world fertilizer nitrogen (N) consumption approaches 100 million tonnes, agriculture in particular must manage fertilizer $\mathrm{N}$ more efficiently for grain production and to minimize adverse environmental impact. Current practices where almost all nitrogen is applied preplant for wheat production are not environmentally sensitive nor do they optimize fertilizer use. Methods to increase nitrogen-use efficiency are sorely needed.
(2) Preplant soil testing that can determine the soil-available ammonium and nitrate forms of nitrogen is valuable, but nitrogen response varies considerably from year to year and from field to field.

(3) Nitrogen-rich strips applied preplant in wheat production fields can assist farmers in determining accurate midseason fertilizer $\mathrm{N}$ rates.

(4) A variant of this methodology, ramp calibration strips, offers midseason visual interpretation of $\mathrm{N}$ demand and an applied method for optimizing fertilizer $\mathrm{N}$.

\section{INTRODUCTION}

Nitrogen $(\mathrm{N})$ fertilizer is the most expensive input for cereal production worldwide. What is probably most important about nitrogen requirements in cereal crop production is that the demand changes drastically from field to field and from one year to the next. Of all the information that should be communicated to farmers in any locale is that this temporal and spatial dependency influences optimum nitrogen fertilizer rates. Long-term winter wheat (T. aestivum $\mathrm{L}$.) research in the southern Great Plains of the US has shown that the average fertilizer- $\mathrm{N}$ application rates would have been correct in the ensuing year only $20 \%$ of the time; yet, using the same rate from one year to the next is common practice for wheat, maize (Zea mays L.), and rice (Oryza sativa
L.) farmers worldwide. In addition, extensive research has shown that indigenous soil $\mathrm{N}$ across the landscape can vary several-fold, resulting in very different $\mathrm{N}$ recommendations depending on the location within the field. In this chapter, we describe two alternatives which improve upon current methods for determining fertilizer $\mathrm{N}$ rates and have the flexibility to be used in environments ranging from 260-ha fields in the High Plains of the US to 1-ha fields in Sub-Saharan Africa (SSA).

A direct measure of $\mathrm{N}$ requirement can be made with the ramp calibration strip (RCS), which is superimposed on farmer practices at or near planting. A range of $\mathrm{N}$ rates (zero to more than sufficient) is applied mechanically or by hand. The RCS is urgently needed in wheat production because $\mathrm{N}$ response varies considerably 
from year to year and from field to field. Soil testing procedures for $\mathrm{NH}_{4}-\mathrm{N}$ and $\mathrm{NO}_{3}-\mathrm{N}$ are valuable, but when taken at or near planting they cannot compensate for subsequent effects of the environment, especially in winter wheat that usually encumbers over 240 days in its growth cycle. The RCS allows farmers to make a visual or optical-sensor interpretation midway through the growing cycle and an ensuing $\mathrm{N}$ rate adjustment based on expected N response. Similarly, the N-rich-strip methodology that envelopes yield potential prediction has proven to be a reliable method for improving fertilizer $\mathrm{N}$ application in cereal production (www.nue.okstate.edu). Applying all N preplant for wheat, well known to be an inefficient method of applying fertilizer $\mathrm{N}$, is no longer advisable, since field-tested alternatives are available.

\section{NITROGEN-USE EFFICIENCY AS A DRIVER OF NEW TECHNOLOGY}

Creating quantifiable methodologies to determine optimal rates of soil nutrient inputs that can be used both in high-production, large-scale, hightechnology production systems and in developing-world single-hectare farms is a daunting task. Nonetheless, we must make the effort to package scientific results in forms applicable to all agricultural environments encountered in wheat production regions around the world. None of the existing methods for determining plant nutrient needs are easily scalable or readily adoptable by farmers in these diverse environments. The approaches described herein are scalable, and they have the potential of being adopted in myriad situations in developed versus developing regions, in stress versus limited-stress environments, or by small-scale versus large-scale farms.

In both wheat and maize production systems, preplant application has been documented as being the most inefficient method of applying fertilizer N (Mahler et al., 1994; Randall et al., 2003). Split-N application increases nitrogen-use efficiency (NUE) in cereal production systems by taking advantage of the improved efficiency of applying $\mathrm{N}$ fertilizer midway through the growing season. Nitrogen-use efficiency is defined as grain $\mathrm{N}$ uptake in fertilized plots minus grain $\mathrm{N}$ uptake in nonfertilized plots, divided by the $\mathrm{N}$ rate applied. With this in mind, methods that improve upon present approaches for midseason fertilizer $\mathrm{N}$ applications will ultimately deliver increased NUE, will improve farmer profitability, and will minimize adverse environmental impact.

Recent research to develop optical sensors and the requisite agronomic science has now provided tools to allow optimization of $\mathrm{N}$ use, which is the most significant input for wheat production. Of the more than 56 million tonnes of fertilizer $\mathrm{N}$ applied to all cereal crops each year, $66 \%$ is not recovered by the crop, some of which is immobilized in the soil and the remainder is lost via denitrification, volatilization, gaseous plant $\mathrm{N}$ loss, leaching, and surface runoff (Raun and Johnson 1999). If NUE could be improved from the current level of 33\% (Raun and Johnson 1999) to more than $50 \%$, the annual world savings would exceed $\$ 10.8$ billion. Since 1992, scientists at Oklahoma State University have been working on the development of an optical-sensor-based approach to improve fertilizer NUE in wheat and other cereal crops. In 1998, the first active lighting sensor was successfully used to accurately predict cereal grain yield potential from midseason vegetative readings. Output from this sensor was later adapted to accurately predict midseason fertilizer $\mathrm{N}$ needs and to improve NUE (Raun et al., 2002). Farmers using the sensor on wheat and maize have realized average increases in revenue exceeding $\$ 20 /$ ha. While this technology has been successfully extended in Mexico, India, Argentina, Pakistan, Australia, Canada, and the US, it must be modified to produce an inexpensive optical pocket sensor that can be extended even further. Science-based decision-making algorithms must be modified for the crops and needs of developing-world farmers.

Judicious and prudent use of $\mathrm{N}$ fertilizer has never been more important, especially 
considering the rapid escalation of natural gas price and the adverse environmental effects of irresponsible $\mathrm{N}$ use. This importance is amplified by the yield and nutritional penalties from not having applied sufficient $\mathrm{N}$. The key to successfully introducing these technologies and scientific developments to farmers in the developed and developing world is the creation and extension of a comprehensive package of technology, science, education, and financing. In the absence of an entire package or system these technologies and scientific breakthroughs will not be adopted. The optical-sensor-based systems further described can provide the agronomic science and sensing technology components of this package.

\section{CASE STUDY: WHAT DEFINES DIVERSE ENVIRONMENTS}

Improved $\mathrm{N}$ management has never been more important than it is today, whether or not the environment is diverse and challenged in some way. Because fertilizer $\mathrm{N}$ used in cereals accounts for more than $60 \%$ of the total N (Alexandratos 1995 , p. 190) used worldwide (90 million tonnes), maize, wheat, and rice farmers are the obvious target when accusations of mismanagement arise. An examination of fertilizer consumption and production data from Sub-Saharan Africa (SSA) and the US illustrate the importance of addressing the problem of imprecise use of $\mathrm{N}$ fertilizer (Table 10.1).

Today, SSA has a population exceeding 699 million persons. In 2005, SSA produced $97,317,420$ t of cereal grain on $88,435,068$ ha, or a mean of $1.10 \mathrm{t} \mathrm{ha}^{-1}$. A total of $26,801,040 \mathrm{ha}$ of maize was harvested in SSA, with a total production of 40,473,062 $t$, or a mean maize yield of $1.51 \mathrm{t} \mathrm{ha}^{-1}$ (Food and Agriculture Organization 2007). Wheat, sorghum (Sorghum bicolor L.), rice, and millet (Pennisetum glaucum L.) comprise the majority of the remaining cereal production (Table 10.1). Alternatively, the US produced $364,019,526 \mathrm{t}$ of cereal grain on $56,404,000$ ha, resulting in $6.50 \mathrm{t} \mathrm{ha}^{-1}$. Fertilizer $\mathrm{N}$ consumption for SSA in 2005 was $1,307,443 \mathrm{t}$, of which $60 \%$ was estimated to be consumed for cereal production (Alexandratos 1995, p. 190). This translates into an anemic average $\mathrm{N}$ rate of $4 \mathrm{~kg} \mathrm{ha}^{-1}$ for more than 88 million hectares of cereals produced in SSA. In the US, 6,526,998 $\mathrm{t}$ of fertilizer $\mathrm{N}$ was consumed for cereal production, and the average annual $\mathrm{N}$ rate was $52 \mathrm{~kg} \mathrm{ha}^{-1}$ for all cereals. While SSA represents $10 \%$ of the world population, it
Table 10.1 Production and nitrogen use statistics for cereal production in Sub Saharan Africa (SSA), the US, and worldwide.

\begin{tabular}{lccc}
\hline & SSA & \multicolumn{2}{l}{ World } \\
\hline Population & $\mathbf{6 9 9 , 8 1 3 , 0 0 0}$ & $\mathbf{3 0 0 , 0 0 0 , 0 0 0}$ & $\mathbf{6 , 6 0 0 , 0 0 0 , 0 0 0}$ \\
Cereal production (ha) & $\mathbf{8 8 , 4 3 5 , 0 6 8}$ & $\mathbf{5 6 , 4 0 4 , 0 0 0}$ & $\mathbf{6 5 7 , 0 8 5 , 6 2 0}$ \\
Maize (ha) & $26,801,040$ & $30,081,820$ & $138,163,504$ \\
Wheat (ha) & $2,631,932$ & $20,226,410$ & $210,247,188$ \\
Sorghum (ha) & $25,829,881$ & $2,301,470$ & $41,689,272$ \\
Rice (ha) & $8,477,895$ & $1,352,880$ & $147,455,159$ \\
Millet (ha) & $20,480,119$ & 200,000 & $34,242,897$ \\
Cereal production (t) & $\mathbf{9 7 , 3 1 7 , 4 2 0}$ & $\mathbf{3 6 4 , 0 1 9 , 5 2 6}$ & $\mathbf{6 9 3 , 4 2 7 , 8 2 5}$ \\
Maize production (t) & $40,473,062$ & $280,228,384$ & $601,815,839$ \\
Cereal yields (t ha ${ }^{-1}$ ) & 1.10 & 6.45 & 1.06 \\
Maize yields (t ha $\left.{ }^{-1}\right)$ & 1.51 & 9.32 & 4.36 \\
Fertilizer N (t) & $1,307,443$ & $10,878,330$ & $84,746,304$ \\
Fertilizer N, cereals (t) & 784,466 & $6,526,998$ & $50,847,782$ \\
N rate, cereals $\left(\mathrm{kg} \mathrm{ha}^{-1}\right)$ & $\mathbf{3 . 9 9}$ & $\mathbf{5 2 . 0 7}$ & $\mathbf{3 4 . 8 2}$ \\
$\mathrm{N}$ fertilizer costs $(\$)$ & $706,019,220$ & $5,874,298,200$ & $45,763,004,160$ \\
\hline
\end{tabular}

Source: Food and Agriculture Organization (2007). 
consumes less than $1.5 \%$ of the world fertilizer N. The US consumed $10,878,330 \mathrm{t}$ of total fertilizer $\mathrm{N}$ in 2005 , or $13 \%$ of the world total, with less than $5 \%$ of the world population. However, in either case, farmers likely are inaccurately and imprecisely estimating the actual nitrogen demand of the crop.

Malakoff (1998) estimated that excess $\mathrm{N}$ flowing down the Mississippi River was valued at over $\$ 750$ million. With increased $\mathrm{N}$ prices, that value now exceeds $\$ 1.0$ billion per year. This becomes increasingly important considering that SSA spent only $\$ 706$ million on fertilizer $\mathrm{N}$ in 2005 for $88,435,068$ ha of cereal production, while the US spent $\$ 5.8$ billion on $\mathrm{N}$ fertilizer for over $56,404,000$ ha of cereal production. While cereal farmers are making some effort to improve upon their fertilizer use efficiency, it is disturbing to note that the excesses from fertilizer $\mathrm{N}$ loss that end up in the Mississippi River each year exceed the total amount of $\mathrm{N}$ fertilizer applied for cereal production in SSA.

The underlying message is that existing technologies for optimizing the use of nitrogen fertilizers can be increased in all agricultural environments. The consequence has been either gross overapplication of $\mathrm{N}$ in regions with high levels of mechanization and abundant supplies of $\mathrm{N}$ fertilizer or gross underapplication in regions of limited $\mathrm{N}$ supply and small farms. The failure of existing technologies to determine optimal $\mathrm{N}$ application rates has been a compelling incentive to develop robust, simple, and flexible methods for determining $\mathrm{N}$ application rates to correct $\mathrm{N}$ deficiencies.

\section{IS NITROGEN NEEDED}

The fundamental question that must be answered for all nutrients is, "Is it needed?" The appropriate application rate is consequential to determining whether or not added amounts of the nutrient in question are needed. While simple and seemingly straightforward, this question is not always properly addressed, regardless of productivity level of a particular operation. With current approaches to soil testing, the decision to apply $\mathrm{N}$ is determined using chemical analysis of surfaceand subsurface-soils for $\mathrm{NH}_{4}-\mathrm{N}$ and $\mathrm{NO}_{3}-\mathrm{N}$ levels. If these surface and subsurface levels of inorganic $\mathrm{N}$ are high, the demand for $\mathrm{N}$ can be small (Ferguson et al., 1991, 2002). However, increased amounts of inorganic $\mathrm{N}$ are normally associated with an increased risk of $\mathrm{NO}_{3}-\mathrm{N}$ leaching (Andraski et al., 2000). Despite the ability to detect excesses in inorganic $\mathrm{N}$ in soil profiles, soil testing in US wheat production is not routine. As a result, future broad adoption of soil testing for $\mathrm{N}$ in the developed or developing world is not expected, nor is it expected to be a future solution of $\mathrm{N}$ management in wheat. In this regard, the identification of any technology that improves upon poor $\mathrm{N}$-use efficiency present today will help in the long term.

Two fundamental reasons for the shortfall in using soil chemical analysis to determine $\mathrm{N}$ levels is the high mobility of nitrate $\mathrm{N}$ and the variation in available nitrate $\mathrm{N}$ as a consequence of changes in the soil environment from year to year. This problem is further compounded by variable availability of $\mathrm{N}$ throughout a given field. The former is termed temporal variability and the latter spatial variability.

\section{Importance of spatial variability on $\mathrm{N}$ requirement}

The applied question of whether or not $\mathrm{N}$ should be applied can be answered by applying a N-rich strip (NRS) in each field and each year. The NRS is essentially a rate of preplant fertilizer that will ensure no $\mathrm{N}$ deficiency is encountered in the crop throughout the growth cycle. Preplant fertilizer is by far the most inefficient method of applying $\mathrm{N}$ and that should be discouraged. Any methodology that works to partition the total amount of $\mathrm{N}$ to be applied will provide improved NUE versus preplant $\mathrm{N}$ applications. The NRS, as it is applied in a portion or strip of the field as the name implies, serves simply as a guide for midseason $\mathrm{N}$ determination. Having the NRS in no way replaces the need to apply a modest rate of preplant $\mathrm{N}$.

As was reported by Ortiz-Monasterio and Raun (2007), many farmers worldwide have historically 
applied excessive amounts of $\mathrm{N}$, and as a result, soil-profile inorganic $\mathrm{N}$ levels can be quite high. The demand for midseason $\mathrm{N}$ is then gauged via observable differences in plant growth at the time top-dress or side-dress $\mathrm{N}$ is usually applied. This can be further refined using a GreenSeeker normalized difference vegetation index (NDVI) sensor (Ukiah, CA; www.ntechindustries.com), combined with online algorithms for wheat and other crops (www.nue.okstate.edu) that determine precise $\mathrm{N}$ fertilizer needs as discussed later in this chapter. The NDVI measurement essentially provides an accurate estimate of the total amount of biomass present by accounting for the amount of red and near-infrared light absorbed (or reflected) by the plant canopy (Moges et al., 2004). By having an estimate of total biomass, yield potential can then be estimated by dividing biomass by the total number of days from planting to sensing in which growing degree day values $\left[\mathrm{GDD}=\left(T_{\min }+T_{\max }\right) / 2-4.4^{\circ} \mathrm{C}\right]$ were positive. This estimate, which is termed the in-season estimate of yield, essentially provides a value for growth rate, or biomass produced per day (Raun et al., 2005).

In other studies examining spatial variability, researchers have found that optimal nitrogen fertilizer rates vary widely from field to field (Cerrato and Blackmer 1991; Schmitt and Randall 1994; Bundy and Andraski 1995). In regions where spatial variability is present, using the average optimum $\mathrm{N}$ rate across a given region would be inadvisable in many of the fields. Other studies have evaluated both temporal and spatial variability and quantified their relative importance. It is interesting that two of these studies, one with rainfed maize in the midwestern US and the other with irrigated wheat in the Yaqui Valley of Mexico, concluded that spatial variability was three times more important than temporal variability (Babcock 1992; Lobell et al., 2004).

\section{Importance of temporal and spatial variability combined}

Recent work by Raun et al. (2008) highlights the importance of placing a NRS or RCS in each field, every year. The RCS approach is a variant of the NRS: instead of having one high $\mathrm{N}$ rate and the farmer-practice $\mathrm{N}$ application, an automated system is developed to apply a range of $\mathrm{N}$ rates at fixed intervals. When evaluated during the crop season, the RCS provides a visual response curve (Raun et al., 2008). This is recommended because the demand for fertilizer $\mathrm{N}$ differs each year as a function of the environment, and in each field as a function of the soil type and previous management practices. Therefore, the only way to decipher $\mathrm{N}$ need is to index temporal and spatial variability. Similar research by Miao et al. (2006) showed that the economically optimum $\mathrm{N}$ rate for maize production averaged $125 \mathrm{~kg} \mathrm{ha}^{-1}$, but that it varied from 93 to $195 \mathrm{~kg} \mathrm{ha}^{-1}$.

Long-term winter wheat grain yield data from check (no $\mathrm{N}$ applied) and fertilized $\left(112 \mathrm{~kg} \mathrm{~N} \mathrm{ha}^{-1}\right)$ plots are reported in Fig. 10.1.

Fig. 10.1 Winter wheat grain yield means from long-term Experiment 502 at Lahoma, Oklahoma. Plots received no $\mathrm{N}$ fertilizer $\left(0 \mathrm{~kg} \mathrm{~N} \mathrm{ha}^{-1}\right)$ or were annually fertilized (112 kg N ha ${ }^{-1}$ ).

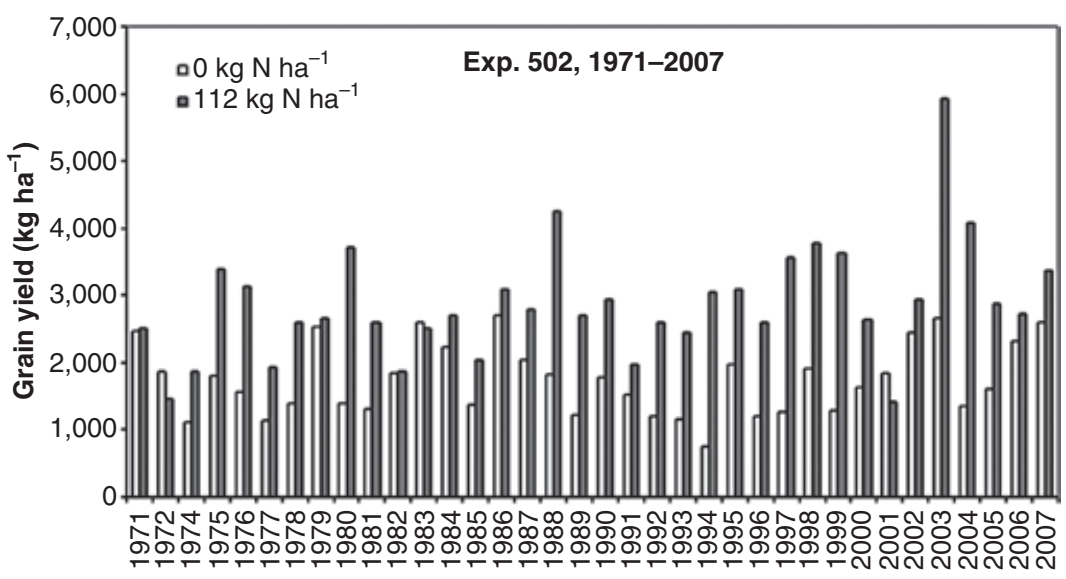


These long-term trials were conducted in an area that received the same management practices from year to year. In this case, winter wheat was grown under conventional tillage, planted in October, and harvested between June and July. Evident from this work is that the demand for fertilizer $\mathrm{N}$ changed dramatically each year and this demand was unpredictable, similar to maize results reported by Miao et al. (2006). The variable demand for fertilizer $\mathrm{N}$ represents the influence of the environment (rainfall and temperature), soil type, and previous crop management on yield potential, which in turn can affect $\mathrm{N}$ responsiveness. Factors which impact yield potential are numerous, unpredictable, and change each year. This could include variable plant stand due to moisture stress, delayed planting due to excessive autumn rainfall, surface soil crusting, in-season moisture stress, diseases (various), lodging, soil type, and previous history of fertilizer use.

From the same data presented in Fig. 10.1, the optimum mean fertilizer $\mathrm{N}$ rate that resulted in maximum wheat grain yields from 1971 to 2006 was $56 \mathrm{~kg} \mathrm{~N} \mathrm{ha}^{-1}\left( \pm 42 \mathrm{~kg} \mathrm{~N} \mathrm{ha}^{-1}\right)$, and the optimum rate varied from 1 to $156 \mathrm{~kg} \mathrm{~N} \mathrm{ha}^{-1}$ (Fig. 10.2). Thus, fertilizing based on the mean optimum rate was only appropriate in 6 of 35 years, or $17 \%$ of the time. Oklahoma State University has numerous long-term experiments which document fertilizer $\mathrm{N}, \mathrm{P}$, and $\mathrm{K}$ response as a function of time in winter wheat (Raun 2008a). All of the long-term winter wheat trials scattered across the state of Oklahoma confirmed this observation that optimum $\mathrm{N}$ rates change drastically from year to year.

If the optimum $\mathrm{N}$ rates are known to change significantly both spatially and temporally, it is intuitive that yield levels, and yield potential, will change accordingly. Hence Raun et al. (2002, 2005) focused on the development of algorithms that could predict yield potential and determine $\mathrm{N}$ rates based on projected removal. The central component of this approach is recognizing the need to predict yield potential from sensor readings based on midseason NDVI. While straightforward, it is complicated by the fact that $\mathrm{N}$ responsiveness, or the response index (RI), must be determined separately. In each field, $\mathrm{N}$ is applied in one strip at a rate where $\mathrm{N}$ will not be limiting through the season. While it is recognized that this method of application is highly inefficient, it is only being used in one portion of the field. In this regard, it is important to recognize that $\mathrm{N}$ responsiveness is independent of yield potential. Furthermore, although $\mathrm{N}$ responsiveness like yield potential is dependent upon spatial and temporal variability, the same variables (total rainfall) can impact $\mathrm{RI}$ and $\mathrm{YP}_{0}$ differently, where $\mathrm{YP}_{0}$ is the yield potential that can be achieved with no added fertilizer applied.

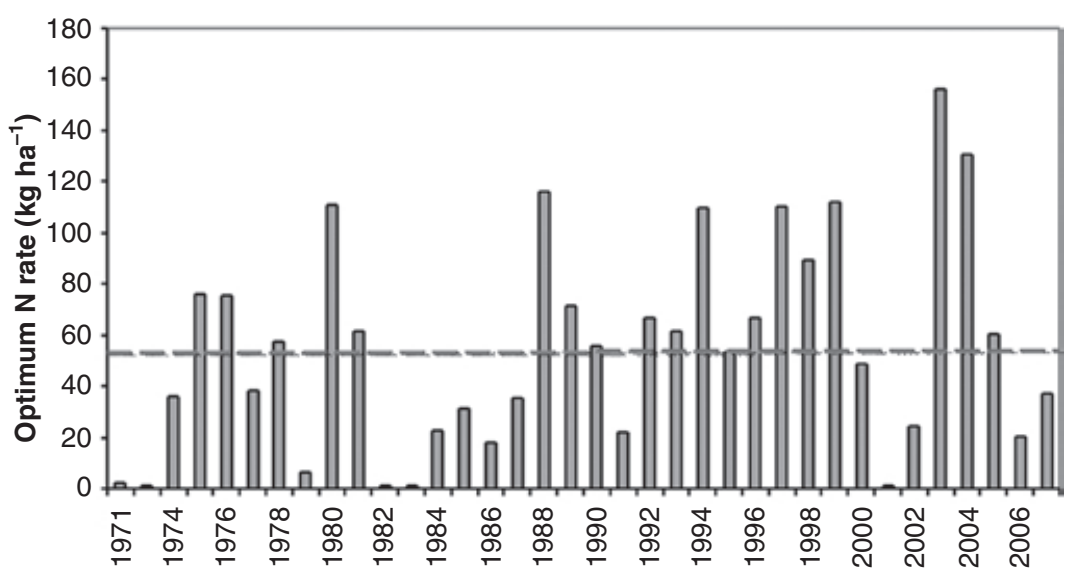

Fig. 10.2 Optimum fertilizer $\mathrm{N}$ rate, by year, from longterm Experiment 502 and the overall mean from 1971 to 2006, at Lahoma, Oklahoma. 


\section{NUTRIENT DEFICIENCIES OTHER THAN N}

Where $\mathrm{N}$ is available, a costly mistake that can be made is applying this precious resource when it is not needed, or when yield response is limited by something else. On-farm trials that clearly target yield response as a result of the application of one factor while holding all others in nonlimiting amounts is an especially useful research and extension tool. Elimination of other confounding effects, including soil $\mathrm{pH}$, soil test $\mathrm{P}, \mathrm{K}, \mathrm{S}$, and/or micronutrients can be easily detected from comprehensive laboratory analyses. Submitting a surface $(0-15$ or $0-30 \mathrm{~cm})$ soil sample for routine and/or comprehensive analysis is always recommended to eliminate the possible needs and/or correction of a deficiency or toxicity of another element. Soil testing to a certain extent is very much a scalable technology that historically has been underutilized, and as such, underappreciated.

The experimental method requires that we do our best to remove the influence of all possible factors, excluding the variable of interest. Thus, a $\mathrm{N}$-rate experiment on $\mathrm{P}$-deficient soils requires that we apply a sufficient rate of $P$ so that $P$ is not limiting. In this same light, we cannot recommend a $\mathrm{N}$ application in a low-vigor area of the field that may actually be P-deficient. The lowvigor area could also be low in soil organic matter, or it may have a shallow A-horizon, or low $\mathrm{pH}$, or one of a host of other yield constraints. Similarly, in portions of the field that exhibit high vigor without some kind of reference, it would be difficult to discern the maximum level of vigor if $\mathrm{N}$ was moderately limiting at that end of the spectrum. The only way to know is to have a reference strip for $\mathrm{N}$ response.

\section{PREDICTION OF YIELD POTENTIAL}

Nitrogen fertilizer is critical for plant growth and grain yield of cereal crops, of which maize, wheat, and rice are the principal crops grown in the world. It has been very difficult to optimize the application of nitrogen fertilizer because it is rapidly transformed in soils and, when in the $\mathrm{NO}_{3}-\mathrm{N}$ form, is highly mobile. Nitrogen fertilizer is also relatively expensive because of the high energy costs associated with its manufacture. Because $\mathrm{N}$ is critical for the production of cereal grains, farmers may resort to one of two extreme $\mathrm{N}$ application strategies: (i) apply $\mathrm{N}$ fertilizer in excess when sufficient fertilizer is available and cost is not excessive or (ii) apply little or none if only limited amounts of $\mathrm{N}$ are available and costs are high. In either case, there is no inexpensive scientifically based device or management system available for use by farmers to determine nitrogen fertilizer rates. Examining the evolving science and technology for managing $\mathrm{N}$ fertilizer and how it can be delivered to a range of environments and production systems reveals that midseason sensing technologies will likely play a role. This is especially evident in Fig. 10.1, where the mean yields from the fertilized plots $\left(112 \mathrm{~kg} \mathrm{~N} \mathrm{ha}^{-1}\right)$ varied from 1,500 to $6,000 \mathrm{~kg} \mathrm{ha}^{-1}$. The mean yield of the fertilized plots and unfertilized plots was $2,862 \pm 860$ and $1,720 \pm 517 \mathrm{~kg} \mathrm{ha}^{-1}$, respectively, over this 35 -year period. Using these numbers, the range in grain produced per kilogram of $\mathrm{N}$ applied was $13.4-53.5 \mathrm{~kg}$. The common rule for winter wheat $(2 \mathrm{lb} \mathrm{N}$ per bushel of wheat you hope to grow) translates to $30.0 \mathrm{~kg}$ grain per kilogram of $\mathrm{N}$. Clearly, the demand for $\mathrm{N}$ is a function of yield potential, and that is known to change considerably by year and by field.

Focusing on the ability to predict grain yield midway through the growing season will become increasingly more important as we strive to match $\mathrm{N}$ fertilizer needs with final removal (Raun et al., 2001). Before proceeding, is it possible to predict yield potential in the middle of the growing season? Early work by Raun et al. (2001) showed that winter wheat grain yield potential could be predicted using multiple NDVI sensor readings collected midseason. This same approach was later modified to use one NDVI sensor reading, adjusted for the number of days from planting to sensing (Raun et al., 2005). The in-season estimated yield (INSEY) was successful in predicting yield potential when evaluated across 30 locations and 6 years. Other researchers have attempted to predict wheat yield potential, but the procedures 
require complicated stochastic methods using data collected from previous harvests (Brooks et al., 2001).

\section{PREDICTION OF N RESPONSIVENESS INDEPENDENT OF YIELD POTENTIAL}

Yield prediction is but part of the process when arriving at an optimal fertilizer $\mathrm{N}$ rate. As noted earlier the crop's response to $\mathrm{N}$ fertilizer changes radically from year to year as a function of the rate of conversion of organic $\mathrm{N}$ to inorganic $\mathrm{N}$ (Johnson and Raun 2003), as well as from field to field as a function of soil type and previous management. Furthermore, the same NDVI sensors used to predict wheat grain yield potential can also be used on the NRS and the area surrounding the NRS (hereafter termed farmer practice) to predict $\mathrm{N}$ responsiveness, or what is termed the response index (RI, estimated as NDVI collected from the NRS divided by NDVI from the farmer practice) (Mullen et al., 2003). Mullen et al. (2003) showed that the RI from NDVI readings $\left(\mathrm{RI}_{\mathrm{NDVI}}\right)$ was highly correlated with final grain yield in the NRS divided by final grain yield in the farmer practice, or the harvest response index $\left(\mathrm{RI}_{\text {harvest }}\right)$. This positive and strong relationship confirmed that $\mathrm{N}$ responsiveness could be predicted across a wide range of yield levels from midseason indirect measurements, such as NDVI.

Once it was recognized that crop response to $\mathrm{N}$ fertilizer could be predicted from early-season sensor readings, this agronomic component was combined with yield potential at no additional $\mathrm{N}$ $\left(\mathrm{YP}_{0}\right)$ (Raun et al., 2001) to estimate crop yield with sufficient $N, Y_{P_{N}}$ (Raun et al., 2005). The fundamental relationship was $\mathrm{YP}_{0} \times \mathrm{RI}=\mathrm{YP}_{\mathrm{N}}$. By estimating the amount of $\mathrm{N}$ taken up by the crop (yield potential if fertilized, $\mathrm{YP}_{\mathrm{N}}$, and yield potential without added fertilizer, $\mathrm{YP}_{0}$ ), the deficit or added amount needed to achieve maximum or near-maximum yields was that amount of $\mathrm{N}$ required to produce the predicted difference in grain yield $\left(\mathrm{YP}_{\mathrm{N}}-\mathrm{YP}_{0}\right)$. This calculation was further refined by accounting for the expected efficiency of the midseason $\mathrm{N}$ applied (usually between 0.5 and 0.7 based on agronomic data collected from a wide range of environments) and the maximum possible grain yield for each specific environment.

The improved midseason $\mathrm{N}$ management approaches have resulted in documented increases in NUE exceeding 15\% (Raun et al., 2002). Extensive on-farm evaluation of the Sensor Based Nitrogen Rate Calculator for wheat and maize has shown a minimum increase in farmer revenue of $\$ 22.00 \mathrm{ha}^{-1}$ when using the recommended $\mathrm{N}$ rate in wheat (Ortiz-Monasterio and Raun 2007), and over $\$ 40.00 \mathrm{ha}^{-1}$ in maize.

The majority of this work has focused on delivering improved $\mathrm{N}$ rates at the field scale where only temporal variability is addressed. However, spatial variability, as well as temporal variability, can be addressed with this methodology and is more profitable (Biermacher at al., 2006), but that requires increased investment in sensing equipment that can be adapted to virtually any fertilizer applicator for midseason fertilizer application in cereals (NTech Industries, www.ntechindustries. com). Their systems employ the algorithm $\mathrm{YP}_{0} \times$ $\mathrm{RI}=\mathrm{YP}_{\mathrm{N}}$ as discussed earlier in this section, and they too have delivered increased farmer profit using this approach for winter wheat, spring wheat, and maize.

The combined knowledge of fluctuating yield levels spatially within a field and changes in additional $\mathrm{N}$ availability from one year to the next demands that a $\mathrm{N}$ application rate be determined midway through the crop season. This, coupled with knowledge of plant stands and vigor obtained from early season growth, provides an accurate method of applying a judicious fertilizer rate.

\section{MIDSEASON N APPLICATIONS CAN RESULT IN MAXIMUM YIELDS}

Provided N is applied later, early-season N stress seldom results in decreased grain yield in winter wheat or spring wheat. Thus, midseason $\mathrm{N}$ applications are much more efficient, and as a result of this improved efficiency, lower amounts of $\mathrm{N}$ are required relative to a preplant $\mathrm{N}$ application to produce the same level of yield (Morris et al., 
2006). In winter wheat, the life cycle from planting to harvest can exceed 240 days. Unlike spring wheat and hybrid maize production cycles that seldom exceed 110 days (planting to physiological maturity), the growth cycle of winter wheat is long enough that corrections can be made inseason, if a deficiency exists. Raun et al. (2002) showed that $\mathrm{N}$ applications delayed until Feekes growth stage 5 (Large 1954) could still result in maximum or near-maximum grain yields over four sites and two years in winter wheat. It is important to note differences between wheat and maize, since maize will remove almost double the amount of total $\mathrm{N}$ in the grain in one-half the time. Because of the shorter growth cycle and increased total $\mathrm{N}$ uptake, getting behind early in the growth cycle of maize can lead to decreased grain yields even if additional $\mathrm{N}$ is applied (Varvel et al., 1997). In addition, wheat can better recover than maize from midseason $\mathrm{N}$ applications because wheat can produce later tillers to compensate, whereas maize cannot set additional ears.

\section{DETERMINATION OF MIDSEASON N RATE}

The response to fertilizer $\mathrm{N}$ is dependent on the supply of nonfertilizer $\mathrm{N}$ (e.g., mineralized from soil organic matter, deposited in rainfall) in any given year. This is attributed to the extensive differences in annual rainfall and temperature and associated change in crop need (temporal variability), which directly influences how much nonfertilizer $\mathrm{N}$ is used by the crop.

The NRS, where $\mathrm{N}$ is not limiting, defines the sensor NDVI value at which $\mathrm{N}$ fertilizer is no longer limited. The highest NDVI measurement along the NRS can be used to calculate the maximum potential yield. Thus when $\mathrm{N}$ is not limiting for the year of measurement, $\mathrm{YP}_{\max }$ is the maximum yield that can be expected within the most productive area in a field.

Three equations are used to calculate $\mathrm{N}$ fertilizer rates. Yield potential or $\mathrm{YP}_{0}\left(\mathrm{Mg} \mathrm{ha}^{-1}\right)$ in winter wheat can be calculated directly by equation 10.1 , where INSEY equals NDVI divided by the number of days from planting to sensing in which growing degree day values are positive $\left[\mathrm{GDD}=\left(\mathrm{T}_{\min }+\mathrm{T}_{\max }\right) / 2-4.4^{\circ} \mathrm{C}\right]$ :

$\mathrm{YP}_{0}=0.590 \mathrm{e}^{258.2 \mathrm{INSEY}}$

In spring wheat, INSEY is equal to NDVI divided by the number of days from planting to sensing, since with few exceptions all days in the spring wheat cycle will have a positive value for GDD. For winter wheat, many days may occur in which the mean temperature does not exceed $4.4^{\circ} \mathrm{C}$, and as such there is no plant growth. Parameters for equation 10.1 are crop-specific (e.g., winter wheat, spring wheat) and are published at http://www.nue.okstate. The following equations predict the potential yield with additional $\mathrm{N}$ fertilizer, or $\mathrm{YP}_{\mathrm{N}}$, for two sets of conditions:

$$
\begin{aligned}
& \mathrm{YP}_{\mathrm{N}}=\mathrm{YP}_{0} \times \mathrm{RI}_{\mathrm{NDVI}}, \\
& \quad \text { if } \mathrm{NDVI}_{\text {FieldRate }} \geq 0.25 \text { and } \mathrm{YP}_{\mathrm{N}}<\mathrm{YP}_{\text {max }}
\end{aligned}
$$

or

$$
\mathrm{YP}_{\mathrm{N}}=\mathrm{YP}_{\max }, \quad \text { if } \mathrm{YP}_{0} \times \mathrm{PI}_{\mathrm{NDVI}} \leq \mathrm{YP}_{\max }
$$

Our observations over several years indicate that values of NDVI $<0.25$ occur on bare soil or on soil with wheat stands so poor at Feekes growth stage 5 that they will not produce appreciable yields. The second set of conditions for $\mathrm{YP}_{\mathrm{N}}$ simply state that $\mathrm{YP}_{\mathrm{N}}$ cannot exceed $\mathrm{YP}_{\mathrm{MAX}}$, where $\mathrm{YP}_{\mathrm{MAX}}$ is an agronomic optimum identified by farmers and scientists in specific regions.

For wheat, the top-dress $\mathrm{N}$ requirement can then be calculated by:

$R=2.39\left(\mathrm{YP}_{\mathrm{N}}-\mathrm{YP} 0\right) / \eta$

in which $R$ is the $\mathrm{N}$ application rate in $\mathrm{kg} \mathrm{ha}^{-1}$, 2.39 is the percentage $\mathrm{N}$ contained in wheat grain, and $\eta$ is the expected efficiency from top-dress $\mathrm{N}$ application, generally between 0.5 and 0.7 . This expected use-efficiency can vary widely, but should fall within this range for midseason $\mathrm{N}$ applications based on our observations. 


\section{"RAMP" METHOD OF DETERMINING MIDSEASON N RATE}

The GreenSeeker NDVI sensor system has shown promise to farmers in the developed world for predicting yield and $\mathrm{N}$ responsiveness, and ultimately for providing a refined midseason fertilizer $\mathrm{N}$ rate. However, simplified technology may be more affordable in the developing world or for smaller-scale developed world farmers. As a result, we developed the ramp calibration strip approach that can be used to decipher midseason fertilizer $\mathrm{N}$ rates, in much the same fashion, but which does not require the more sophisticated sensor currently used. Similar to the approach described in the previous section, this methodology assumes that waiting until midseason to apply up to one-half of the required $\mathrm{N}$ fertilizer can result in maximum or near-maximum yields. The RCS applicator that we developed applies 16 incremental $\mathrm{N}$ rates at 3- to 6-m intervals over a total distance of 45-90 m (number of rates, intervals, and distances can be adjusted depending on the crop and other conditions) (Raun et al., 2008). Because the RCS is superimposed on the farmer preplant $\mathrm{N}$ practice, producers can observe plant responsiveness over the range of rates to determine the optimum top-dress $\mathrm{N}$ rate. Whether determined visually or with simplified activereflectance-based sensors, the point where midseason visual growth differences no longer exist is the appropriate top-dress $\mathrm{N}$ rate. Where adequate but not excessive preplant $\mathrm{N}$ is available, the ramp interpolated rate provides a direct method to determine how much midseason $\mathrm{N}$ should be applied to achieve the maximum yields based on growth response evidenced within the RCS.

This approach has now been extensively adopted, and several farmers have ingeniously developed their own versions of the RCS with differing ranges in $\mathrm{N}$ rates, widths, and methods of application, depending on their production system, form of tillage, and crop being grown. For each of these variants on the RCS, methodology descriptions on how to build them are reported by Raun (2008b).

For the winter wheat example in Color Plate 24 (taken near Feekes growth stage 5), the RCS top-dress rate would have been near $80 \mathrm{~kg} \mathrm{~N} \mathrm{ha}^{-1}$, the point where total biomass was maximized. Where adequate but not excessive preplant $\mathrm{N}$ is available, the RCS interpolated rate (Fig. 10.3) provides an applied method to determine how much midseason $\mathrm{N}$ should be applied to achieve the maximum yields based on growth response evidenced within the RCS. This type of response is typical and one that can be deciphered either visually or using a hand-held Greenseeker NDVI sensor. As visualized in Color Plate 24 and plotted in Fig. 10.3, it is important to note that the response curves will take on a wide range of forms, and all are highly dependent on temporal vari-

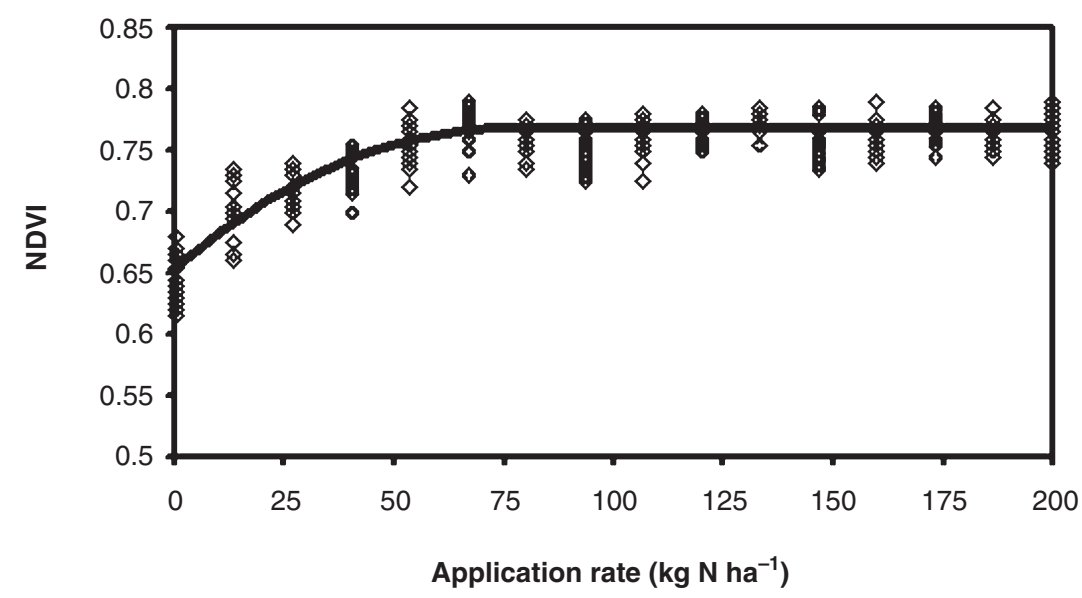

Fig. $\quad 10.3$ Typical optical sensor measurements from a $\mathrm{N}$-calibration ramp as a function of $\mathrm{N}$ application rate. Curves from this graph, adjusted for improvements in $\mathrm{N}$ uptake efficiencies realized by mid-growing-season application of $\mathrm{N}$, can be used to determine optimum $\mathrm{N}$ application. 
ability. Likewise, the optimum $\mathrm{N}$ rate determined from visual or sensor interpretation of the RCS varies accordingly, thus requiring that $\mathrm{N}$ rates be adjusted each year accordingly.

\section{FUTURE PERSPECTIVES}

There are still many unanswered needs relating to improved $\mathrm{N}$ management in cereals. The most important is generating improved yieldprediction equations for midseason $\mathrm{N}$ applications. Current work is tailored at using soil-profile moisture in addition to NDVI values to refine yield estimates, and that is certainly appropriate in rainfed environments where moisture is often limiting. If yield potential can be predicted, nutrient removal can be easily estimated by multiplication with known grain and straw $\mathrm{N}$ concentrations. Basing ensuing fertilizer $\mathrm{N}$ rates on projected removal is logical. Also, added work is needed to tailor $\mathrm{N}$ applications to the growth stage where $\mathrm{N}$ assimilation is the greatest. Applying $\mathrm{N}$ at the exact time when $\mathrm{N}$ demand is the greatest will likely provide a significant boost in resultant NUE.

\section{REFERENCES}

Alexandratos, N. (ed.) 1995. World agriculture: Towards 2010, an FAO study. FAO and John Wiley \& Sons, West Sussex, England.

Andraski, T.W., L.G. Bundy, and K.R. Brye. 2000. Crop management and corn nitrogen rate effects on nitrate leaching. J. Environ. Qual. 29:1095-1103.

Babcock, B.A. 1992. The effects of uncertainty on optimal nitrogen applications. Rev. Agric. Econ. 14:271-280.

Biermacher, J.T., F.M. Epplin, B.W. Brorsen, J.B. Solie, and W.R. Raun. 2006. Maximum benefit of a precise nitrogen application system for wheat. Precision Agric. 7:193-204.

Brooks, R.J., M.A. Semenov, and P.D. Jamieson. 2001. Simplifying Sirius: Sensitivity analysis and development of a meta-model for wheat yield prediction. Eur. J. Agron. $14: 43-60$.

Bundy, L.G., and T.W., Andraski. 1995. Soil yield potential effects on performance of soil nitrogen tests. J. Prod. Agric. 8:561-568.

Cerrato, M.E., and A.M. Blackmer. 1991. Relationship between leaf nitrogen concentrations and the nitrogen status of corn. J. Prod. Agric. 4:525-531.
Ferguson, R.B., G.W. Hergert, J.S. Schepers, C.A. Gotway, J.E. Cahoon, and T.A. Peterson. 2002. Site-specific nitrogen management of irrigated maize: Yield and soil residual nitrate effects. Soil Sci. Soc. Am. J. 66:544-553.

Ferguson, R.B., J.S. Schepers, G.W. Hergert, and R.D. Lohry. 1991. Corn uptake and soil accumulation of nitrogen: Management and hybrid effects. Soil Sci. Soc. Am. J. $55: 875-880$

Food and Agriculture Organization. 2007. FAOSTAT: Agricultural production [Online]. Available at http://faostat. fao.org (verified $19 \mathrm{Feb} .2008$ ).

Johnson, G.V., and W.R. Raun. 2003. Nitrogen response index as a guide to fertilizer management. J. Plant Nutr. 26:249-262

Large, E.C. 1954. Growth stages in cereals: Illustration of the Feekes Scale. Plant Pathol. 3:128-129.

Lobell, D.B., J.I. Ortiz-Monasterio, and G.P. Asner. 2004. Relative importance of soil and climate variability for nitrogen management in irrigated wheat. Field Crops Res. 87:155-165.

Mahler, R.L., F.E. Koehler, and L.K. Lutcher. 1994. Nitrogen source, timing of application, and placement: Effects on winter production. Agron. J. 86:637-642.

Malakoff, D. 1998. Death by suffocation in the Gulf of Mexico. Science 281:190-192.

Miao, Y., D.J. Mulla, P.C. Robert, and J.A. Hernandez. 2006. Within-field variation in corn yield and grain quality responses to nitrogen fertilization and hybrid selection. Agron. J. 98:129-140.

Moges, S.M., W.R. Raun, R.W. Mullen, K.W. Freeman, G.V. Johnson, and J.B. Solie. 2004. Evaluation of green, red and near infrared bands for predicting winter wheat biomass, nitrogen uptake, and final grain yield. J. Plant Nutr. 27:1431-1414.

Morris, K.B., K.L. Martin, K.W. Freeman, R.K. Teal, D.B. Arnall, K. Desta, W.R. Raun, and J.B. Solie. 2006. Midseason recovery to nitrogen stress in winter wheat. J. Plant Nutr. 29:727-745.

Mullen, R.W., K.W. Freeman, W.R. Raun, G.V. Johnson, M.L. Stone, and J.B. Solie. 2003. Identifying an in-season response index and the potential to increase wheat yield with nitrogen. Agron. J. 95:347-351.

Ortiz-Monasterio, J.I., and W. Raun. 2007. Reduced nitrogen for improved farm income for irrigated spring wheat in the Yaqui Valley, Mexico, using sensor based nitrogen management. J. Agric. Sci. 145:1-8.

Randall, G.W., J.A. Vetsch, and J.R. Huffman. 2003. Corn production on a subsurface-drained Mollisol as affected by time of nitrogen application and nitrapyrin. Agron. J. 95:1213-1219

Raun, W.R. 2008a. Long-term soil fertility experiments at Oklahoma State University [Online]. Available at http://www.nue.okstate.edu/Long_Term_Experiments. htm (verified 18 Feb. 2008).

Raun, W.R. 2008b. Predicting the potential response to applied N [Online]. Available at http://www.nue.okstate. edu/Index_RI.htm (verified 19 Feb. 2008).

Raun, W.R., and G.V. Johnson. 1999. Improving nitrogen use efficiency for cereal production. Agron. J. 91:357363. 
Raun, W.R., G.V. Johnson, M.L. Stone, J.B. Solie, E.V. Lukina, W.E. Thomason, and J.S. Schepers. 2001. Inseason prediction of potential grain yield in winter wheat using canopy reflectance. Agron. J. 93:131-138.

Raun, W.R., J.B. Solie, G.V. Johnson, M.L. Stone, R.W. Mullen, K.W. Freeman, W.E. Thomason, and E.V. Lukina. 2002. Improving nitrogen use efficiency in cereal grain production with optical sensing and variable rate application. Agron. J. 94:815-820.

Raun, W.R., J.B. Solie, M.L. Stone, K.L. Martin, K.W. Freeman, R.W. Mullen, H. Zhang, J.S. Schepers, and G.V. Johnson. 2005. Optical sensor based algorithm for crop nitrogen fertilization. Commun. Soil Sci. Plant Anal. 36:2759-2781.

Raun, W.R., J.B. Solie, R.K. Taylor, D.B. Arnall, C.J. Mack, and D.E. Edmonds. 2008. Ramp calibration strip technology for determining mid-season $\mathrm{N}$ rates in corn and wheat. Agron. J. 100:1088-1093.

Schmitt, M.A., and G.W. Randall. 1994. Developing a soil nitrogen test for improved recommendations for corn. J. Prod. Agric. 7:328-334.

Varvel, G.E., J.S. Schepers, and D.D. Francis. 1997. Ability for in-season correction of nitrogen in corn using chlorophyll meters. Soil Sci. Soc. Am. J. 61:1233-1239. 